\title{
Macrothink

\section{Exploring the Roles, Functions and Competencies of Library and Media Teachers in Managing School Resource Centers and Supporting 21st Century Learning in Malaysian Schools}

\author{
Husain Hashim (Corresponding author) \\ Faculty of Information Management, Universiti Teknologi MARA, Malaysia \\ E-mail: husainha@uitm.edu.my \\ Shamila Mohamed Shuhidan \\ Faculty of Information Management, Universiti Teknologi MARA, Malaysia \\ E-mail: shamila@uitm.edu.my
}

Received: December 29, 2019 Accepted: February 3, 2020 Published: March 19, 2020

doi:10.5296/ijld.v10i1.16716 URL: https://doi.org/10.5296/ijld.v10i1.16716

\begin{abstract}
21 st century skills are embedded in the Malaysian school curriculum to prepare and produce knowledgeable and responsible young citizens in coping with the challenges of the global knowledge economy. The trend has an impact on the roles of school resource centers (SRC), which are currently managed by the so-called library and media teachers (LMT). As the LMTs are appointed among school teachers who need to allocate and divide their responsibilities into academic teaching and SRC management, several issues are found from literature pertaining to their overburdened teaching tasks, lack of time and inadequate library management competencies. This has caused further shortcomings in service provision including poor implementation of information literacy and reading programs for school students. A qualitative research approach is adapted to investigate the roles, functions and competencies of LMTs in managing SRCs and supporting 21 st century teaching and learning in the school setting. This study uses semi-structured interviews for data collection involving five (5) LMTs who provided insightful feedback towards understanding the aforementioned issues. The findings reveal essential information with respect to the roles, functions and competencies of LMTs and also identify relevant challenges that can disrupt the provision and delivery of SRC services,
\end{abstract}


facilities and programs. This requires the attention of the government and school administration to enforce a better platform that enables the LMTs to uphold their roles and functions accordingly towards enhancing the 21st teaching and learning environment in Malaysian schools.

Keywords: School resource center, Library and Media Teacher, 21st century learning, Roles and functions, Competencies, Challenges

\section{Introduction}

The dynamism and flexibility of information and communication technology (ICT) is continuously changing the education landscape of the 21 st century. In conjunction with this, education for school students should offer an avenue that allows them to acquire new skills, knowledge and methods of learning, aligned with living and working demands in a complex information environment (Kulhthau, 2010). Within a Malaysian context, the approach of 21st century education can be observed in a holistic manner through the introduction of the National Education Blueprint 2013-2025 by the Ministry of Education of Malaysia (MOE). Apart from underlining the necessities to implement ICT in schools, an essential aspect stated in the Education Blueprint is that every primary and secondary school across the country should be equipped with a school resource center (SRC) by the year 2020 (Ministry of Education of Malaysia, 2013). The Educational Technology Division (ETD) of the ministry is responsible towards ensuring all SRCs focus on the provision of library and educational resources to support and reinforce the quality of the learning processes and its teaching methods.

A guidebook for SRC management (Kementerian Pendidikan Malaysia, 2016), explains the role of SRC for 21 st century learning. An immense job is put on the shoulders of SRCs to inculcate a reading culture among Malaysians who are also well-equipped with information skills. In this respect, a Library and Media Teacher (LMT) is appointed at most SRCs as the gateway to information in print, non-print, electronic and digital formats, which are acquired, organized and made accessible for teachers and students. Under the policy of the MOE, LMTs must be selected and assigned from well-trained and certified teachers from the Institute of Teacher Education or relevant public universities. The LMTs are expected to spend 18 to 20 hours per week to manage SRC, organize library materials, promote reading habits and teach students information skills. They are also allotted 6 to 8 hours per week for class and subject teaching tasks.

\section{Problem Statement}

LMTs are set to be appointed among full-fledged subject teachers. In their hands, supposedly, there are important roles and functions for them to play and carry out, however, only a few LMTs were found to be truly keen to take up this role as it is considered a difficult task (Fadzliation and Kamarulzaman, 2010). The cause being that most LMTs are lacking in training and relevant competencies, as many among them, despite being well-trained teachers, are neither qualified nor professionally trained in Library and Information Science (Kamal and Normah, 2012). In addition, Kamal and Normah (2012) ascertained that LMTs are overburdened with class teaching (more than 6 to 8 class hours) affecting them to have much 
reduced time for managing the SRCs and implementing the expected reading and information literacy programs. Similarly, Aisah et al. (2018) highlights the heavy workload faced by LMTs that there is much time constrain for them to learn new ICT skills for the information literacy program.

Meanwhile, from students' perspective, several problems were also articulated and shared in the literature relating to their shortcomings in information literacy skills, information seeking behaviors and reading habits. Students worry about their exposure to the outside world based on their unlimited capacity to reach online information on the Internet that can potentially lead to confusion, misunderstanding and misuse of information (Kuhlthau, 2010). Evidently, Shuhidan (2013) and Yu (2014) in separate academic studies revealed that Malaysian school students are dragged, whether intentionally or otherwise, into plagiarizing (copying and pasting without proper rephrasing, citing and quoting the works of others) while preparing their school tasks and assignments. According to Shuhidan, Macauley and Reynolds (2013), the crucial problem faced by Malaysian school children relates to their weakness in information seeking behavior, particularly caused by inadequate information literacy and navigation skills in surfing through the Internet.

Highlighting the circumstances surrounding issues between the aspirations and goals formulated by respective Malaysian authorities for SRCs and LMTs, the accumulated problems and limitations faced by students as found in relevant literature, a qualitative study was initiated to explore the roles, functions, competencies and challenges of LMTs. A semi-structured interview was used as data collection to understand the issues being investigated.

\section{Literature Review}

With regards to the literature, several new roles, functions and competencies for school librarians are emphasized. Beyond the traditional role such as dealing with printed books and reading, Cheng (2012) suggests that the role of 21 st century teacher librarians is to work along with other teachers towards collaborative instructional and curriculum planning. Teacher librarian is the job title used in countries like Australia and given similar roles to the LMTs in Malaysia. Cheng (2012) urges teacher librarians to advocate and highlight their roles as information specialists, teaching partners and curriculum resource facilitators. Sharing the same view, Kimmel, Dickinson and Doll (2012) suggests the role of school librarians (the most commonly used title in many countries) should change from being cooperative to becoming a fully collaborative partner with teachers in the delivery of teaching and instruction. As such, Kimmel, Dickinson and Doll (2012) pointed out the competencies that school librarians should crucially uphold that comprise working well with others, network and collaboration as well as, collegiality and professionalism (Kimmel, Dickinson and Doll, 2012).

A library community in Kentucky conducted a survey in 2010, which was to identify the expectations of school principals towards their school library media specialist (SLMS). The survey used the ALA/AASL 5 standards of competency for the principals to rate the frequency that their schools' SLMS demonstrated for each competency (Johnston et al., 2012). Another study adopting the ALA/AASL standards was conducted in Nigeria to explore competencies 
possessed and required by primary school teacher librarians (Dike, Osadebe and Babarinde, 2015).

Johnston et al. (2012) indicates from an online survey that was posted to school administrators, 91\% of 388 participating respondents specified they have SLMS who are appointed in a full-time capacity at their schools. About the professional qualification of the SLMS, 96\% respondents revealed that they have certified SLMS, while the SLMS who possessed a master's degree in Library Science was reflected by $71 \%$ of the participating principals. Another method used in the study was content analysis and, most importantly, the results identified key themes in which there is a correlation between highly qualified SLMS and student academic achievements. Similar results were found in a study from New York by Small, Shanahan and Stasak (2010) that pupils in elementary schools with certified school librarians were more likely to attain higher scores in the English Language Arts standardized tests than those from other schools without certified librarians. Furthermore, Johnston et al. (2012) shares the result of an online survey that shows the most frequently SLMS rated competency ( $74.8 \%$ out of 388 respondents) was the leadership role in the integration of ICT or digital tools and resources by advocating students for 21 st century learning to support their conceptual understanding, critical thinking, and in the creation of processes and designs. The findings are backed by other researchers where school librarians undertake a crucial leadership role in technology integration and technological literacy that becomes a significant aspect of the school librarian profession (Green, Jones and Burke, 2017; Baker, 2016; Kuhlthau, 2010; Hughes-Hassell and Hanson-Baldauf, 2008).

The study carried out by Dike, Osadebe and Babarinde (2015) applies purposive sample through the participation of 16 teacher librarians from the preidentified developed school libraries in Enugu State of Nigeria. 3 instruments were utilized for the purpose of data collection: observation, interview and questionnaire. The questionnaire was meant to gauge the competencies possessed and required by the teacher librarians through self-rating based on the five standards of ALA/AASL. The findings disclose that the respondents perceived that they had high competencies in the aspects of teaching and guiding students in using library sources, developing student's information skills and also promoting literacy and reading programs, relatively better than the advocacy and leadership competencies. However, in contradiction to Johnston et al. (2012), the least possessed competencies rated by the respondents in Enugu are more technical driven. For example in the teaching activities related with ICT usage, such skills required for managing library tasks involving cataloguing, indexing and abstracting, and circulation. This can be understood by the fact that a majority of SLMS in Kentucky is well qualified and certified as compared to those teacher librarians in Enugu who were identified as not being fully qualified.

Meanwhile, within a Malaysian context, the literature underlines more localized issues that show the SRCs and LMTs struggle with their own limitations that may abandon the ability and capacity to play their roles and execute their functions accordingly. As discussed below, some important aspects highlighted are very much associated with the LMTs' lack of competencies that somehow contributes to real challenges that they face and further worsens the issues of students with regards to their information literacy skills, information seeking behavior and 
reading habit.

Aisah, et al. (2018) conducted a survey that investigated the perceived roles and actual practices of LMTs whose SRCs received 4 and 5 star ratings in the 2015 SRC national evaluation exercise, especially for their participation in developing an Information Literate School Community (ILSC) program using Henri's benchmarks (1995). The results exhibited the LMTs were having heavy workloads and were unable to find time to learn and upgrade their ICT skills, which had somehow contributed to the biggest gap that existed between their perceived importance and the actual practice factors pertaining to the integration of ICT in the ILSC program.

Moreover, the LMTs perceived themselves as not ready to conduct internal information literacy training for other teachers. Tan, Kiran and Singh (2015) discovered that the LMTs were doubtful with their own cognitive, functional and technical readiness in information literacy implementation, thus affecting their level of confidence in executing the information specialist role. This is consistent with findings by Yushiana and Norhiyah (2011) that the low usage of SRC among Malaysian high school teachers was due to the fact that the appointed LMTs at their schools did not offer sufficient amount of support to train, promote and implement information literacy programs for teachers and students. Also, teachers were found to have limited awareness about the role an SRC could play in complementing the school curriculum (Yushiana \& Norhiyah, 2011).

In consequence, it was found that students were the ones affected by the abovementioned challenges faced by LMTs. A survey by Mohammad Jafre et al. (2014) was carried out in Penang to examine the online reading habits of students in secondary schools. Out of 240 students who participated in the survey, $83.7 \%$ of them were daily online readers. The study unveiled the main purpose of online reading was for entertainment rather than for educational purposes. This was not a strange finding as upon the introduction of NILAM, an intensive reading program for school students, as stated in Program NILAM: Konsep dan Panduan Pelaksanaan di Sekolah, most of the materials read by students were leisure materials such as magazines, comics and newspapers (Bahagian Teknologi Pendidikan, 2007). In fact, how extensively NILAM has been successful in improving students' choice of quality reading material has yet to be seen. A profound statement publicly made by Datuk Seri Dr Khair Mohamad Yusof, the Director General of Education of Malaysia in 2016, blamed students' poor reading habits towards a weak performance weaknesses in answering Higher Order Thinking Skill (HOTS) questions during examinations (Suhaini, 2016) as the main cause.

\section{Research Objectives}

- To explore the roles and functions of LMTs towards the implementation 21 st century education.

- To investigate the competencies of LMTs in performing their roles and functions.

- To gauge the challenges faced by the LMTs to manage SRCs and provide services for students and teachers. 


\section{Macrothink}

\section{Research Method}

This research adapts a qualitative research approach to investigate the roles, functions and competencies of LMTs in managing SRC and supporting 21st century teaching and learning in the school setting. Exploratory qualitative research is used in this research as it is not intended to provide conclusive evidence, but purposely designed to explore and better understand the problem being studied by looking into LMTs' perceptions and insights related to a phenomenon surrounding the issues of their roles, functions and competencies in regards with SRC management and provision of teaching and learning support in schools.

This study uses semi-structured interview to allow LMTs to respond in detail and to enable them to clarify their responses with more flexibility (Neuman, 2014). It is also intended to gain interpretation based on the LMTs' views from the interviews conducted. As this study uses qualitative data, the number of respondents is large enough to obtain sufficient data to describe the phenomenon being investigated. According to Creswell (1998), it is recommended for phenomenological studies, a minimum of 5 respondents, which can go up to 25 respondents. After obtaining the necessary approval from respective authoritative bodies, five (5) LMTs from various types of schools were selected to participate in the study involving five regions in Malaysia: the Northern Region, Southern Region, Central Region, East Coast Region and Borneo Region.

The interviews asked respondents open-ended questions with reference to the guidebook for SRC management (Educational Technology Division, 2017) and the ALA/AASL Standards for Initial Preparation of School Librarians (American Association of School Librarians, 2010). The respondent's answers were digitally recorded for easier transcription and note taking. Thematic analysis was then applied as a process for encoding the qualitative information. The encoding requires elements such as a list of themes or patterns found in the information that describe and interpret aspects of the phenomena (Boyatzis, 1998).

\section{Findings}


Table 1. An overview of the LMT roles, functions, competencies and challenges based on semi-structured interviews

\begin{tabular}{|c|c|c|c|c|c|c|}
\hline CODE & $\begin{array}{l}\text { TEACHING } \\
\text { EXPERICENCE }\end{array}$ & $\begin{array}{l}\text { SUBJECT } \\
\text { TEACHING }\end{array}$ & $\begin{array}{l}\text { TEACHING } \\
\text { HOURS }\end{array}$ & $\begin{array}{l}\text { ROLES \& FUNCTIONS } \\
\text { AS LMT }\end{array}$ & $\begin{array}{l}\text { COMPETENCIES IN } \\
\text { MANGING SRC AND } \\
\text { SUPPORTING T\&L }\end{array}$ & CHALLENGES \\
\hline LMT1 & 10 years & $\begin{array}{l}\text { Moral } \\
\text { Education }\end{array}$ & 12 hours & $\begin{array}{l}\text { - Management of } \\
\text { learning resources } \\
\text { - Communication and } \\
\text { cooperation with school } \\
\text { administrators, teachers } \\
\text { and parents }\end{array}$ & $\begin{array}{l}\text { - Human } \\
\text { communication } \\
\text { - Library \& information } \\
\text { skills } \\
\text { - ICT skills } \\
\text { - Teaching \&learning } \\
\text { content }\end{array}$ & $\begin{array}{l}\text { - Heavy workload in } \\
\text { teaching \& } \\
\text { co-curriculum }\end{array}$ \\
\hline LMT2 & 12 years & $\begin{array}{l}\text { Moral } \\
\text { Education }\end{array}$ & 12 hours & $\begin{array}{l}\text { - } \text { Management of } \\
\text { learning resources } \\
\text { - Information skills } \\
\text { education } \\
\text { - Teaching responsibility } \\
\text { - Communication and } \\
\text { cooperation with school } \\
\text { administrators, teachers } \\
\text { and parents }\end{array}$ & $\begin{array}{l}\text { - Library science \& } \\
\text { information } \\
\text { management } \\
\text { - Pedagogy } \\
\text { - Creative \& innovative } \\
\text { thinking skills }\end{array}$ & $\begin{array}{l}\text { Lack of staff support } \\
\text { in library works }\end{array}$ \\
\hline LMT3 & 11 years & $\begin{array}{l}\text { Moral } \\
\text { Education }\end{array}$ & 25 hours & $\begin{array}{l}\text { - Library administration } \\
\text { and operations } \\
\text { - Teaching responsibility } \\
\text { - Communication and } \\
\text { cooperation with school } \\
\text { administrators, teachers } \\
\text { and parents }\end{array}$ & $\begin{array}{l}\text { - Library \& information } \\
\text { skills } \\
\text { - Library promotion } \\
\text { - Provision of conducive } \\
\text { and student-friendly } \\
\text { atmosphere }\end{array}$ & $\begin{array}{l}\text { - Heavy workload in } \\
\text { teaching } \\
\text { co-curriculum } \\
\text { - Financial constraint } \\
\text { - Lack of support from } \\
\text { school } \\
\text { administration in } \\
\text { library roles \& } \\
\text { functions } \\
\text { - Library space used } \\
\text { for classes (relief \& } \\
\text { additional) }\end{array}$ \\
\hline LMT4 & 11 years & $\begin{array}{l}\text { Moral } \\
\text { Education }\end{array}$ & $\begin{array}{lr}12 & \text { hours } \\
\text { minimum } & \\
\text { depending } & \text { on } \\
\text { number } & \text { of } \\
\text { students } & \end{array}$ & $\begin{array}{l}\text { - Library administration } \\
\text { and operations } \\
\text { - Communication and } \\
\text { cooperation with school } \\
\text { administrators, teachers } \\
\text { and parents }\end{array}$ & $\begin{array}{l}\text { - Communication skills } \\
\text { - ICT skills } \\
\text { - Resource center } \\
\text { management LMT }\end{array}$ & $\begin{array}{l}\text { - Financial constraint } \\
\text { - Library space used } \\
\text { for classes/ tutorials }\end{array}$ \\
\hline LMT5 & 11 years & $\begin{array}{l}\text { Moral } \\
\text { Education }\end{array}$ & 25 hours & $\begin{array}{l}\text { - Library administration } \\
\text { and operations } \\
\text { - Teaching responsibility } \\
\text { - Co-curriculum activity } \\
\text { - Communication and } \\
\text { cooperation with school } \\
\text { administrators, teachers } \\
\text { and parents }\end{array}$ & $\begin{array}{l}\text { - Library promotion } \\
\text { - Provision of conducive } \\
\text { and student-friendly } \\
\text { atmosphere } \\
\text { - Program (event) } \\
\text { management }\end{array}$ & $\begin{array}{l}\text { - Heavy workload in } \\
\text { teaching \& } \\
\text { co-curriculum } \\
\text { - Library space used } \\
\text { for classes/ tutorials } \\
\text { \& school activities } \\
\text { - Limited library } \\
\text { usage among } \\
\text { students }\end{array}$ \\
\hline
\end{tabular}

Table 1 provides an overview of the LMT roles, functions, competencies needed and also challenges in managing SRC and supporting teaching and learning in a school setting. From the findings, it shows that all LMTs have more than 10 years' experience in teaching and have 
been given moral education as a subject. However, the teaching hours vary from 12 hours up to 25 hours per week. LMT3 and LMT5 have to teach up to 25 hours per week due to the instructions received from the school administration to take up the amount of teaching hours equal to other teachers. As such, LMT1, LMT3 and LMT5 disclosed that they have insufficient time and cannot devote the much-needed time needed towards managing SRCs.

As for their roles and functions, all LMTs highlight that their common duty is to manage the school library/resource center in terms of administration, operations, organization of learning resources and any other activities that are assigned to them besides teaching moral education. LMT2 has detailed out his roles and functions that are relevant to library work. He grouped them into five (5) categories comprising: to plan and implement information literacy programs and resource center services; to supervise and manage materials of SRC (including acquisition, stock and inventory controls, promotional activities and preparation of reports and analysis of program, activities and operations of SRC); to communicate and cooperate with ETD and public libraries for continual improvement of services and programs of SRC; to perform teaching and learning tasks as per scheduled and lastly; to implement academic programs that are to increase teachers' professionalism and students' achievement. All LMTs emphasized the teaching role assigned to them to teach a class subject (moral education), while LMT3 and LMT5 disclosed an additional task given to LMTs in handling and being the advisors to the co-curricular activities of students involving clubs, societies, uniform bodies and sports/games based on what the school administrators have set for them. Regarding the support staff who assisted the LMTs in SRC work, LMT3 and LMT5 mentioned the presence of library support staff and library prefects appointed among students.

Every LMT is consistent in providing education on information literacy skills and promoting reading habits for both students and teachers. Some of the information literacy classes are held in varied ways including one-off and on-going sessions. Among others are library orientation programs for new students, workshops and short courses on citation (APA and MLA), ethics of searching and using information and also basic learning skills. As for reading promotion activities, again various ways are used by the LMTs such as, young reader programs, language week, NILAM programs (initiated by MOE), 10-minute reading events (organized annually by the National Library of Malaysia) and reading merit programs.

With regard to having good communication and cooperation with school administrators, teachers and parents, all LMTs agree that it is a crucial role. LMT1 believes all categories of users should be given equal opportunities to use the services and facilities provided by SRCs. By doing this, users will be able to recognize the relevance of SRCs and keep on offering positive and constructive opinions that will ensure the roles of SRCs are aligned with the school mission. LMT2 relates cooperation between SRCs and school administrators, teachers and parents with students' academic achievement. As such, LMT2 further highlights the need that the SRCs should become a hub for knowledge dissemination through the provision of quality reference and reading materials and effective library activities.

In terms of competencies needed by LMTs, again, a majority of them agree that library science and management of resource centers along the lines of information literacy skills and library 
promotion is needed. LMT1, LMT3 and LMT4 claim in this digital age, ICT skills are crucial as nowadays most of the curriculum is embedded with technology. LMT3 further highlights the importance of ICT skills in association with information literacy skills in regard to searching for valid information on the Internet and ICT usage in support of teaching and learning. Another crucial competency in relation to promoting and increasing students' interests in visiting and utilizing resource services, LMT3, LMT4 and LMT5 draw attention to the need for knowledge in space management and decoration designs in making the atmosphere of resource centers more welcoming and attractive. More specifically, LMT3 underlines the necessity to catch up with the latest trends that would be of interest to students such as providing library space with 'hipster appeal' and library cafés. The next competency as mentioned by LMT1, LMT2 and LMT3 is human communication skills that the LMTs should acquire. This is of course essential in line with the requirements for LMTs to communicate, cooperate and collaborate efficiently with students, teachers, administrators and parents in many relevant aspects. Examples that require good human communication skills are connected to the on-going provision and delivery of services, involvement with collaborative efforts with teachers and, in the proper distribution of information about SRCs' achievements and performance to school administrators, principals and parents. Interestingly, LMT2 articulates the inner human aspects for the LMTs' personality such as being passionate, creative, innovative and also making their presence relevant to others and always becoming a resource person in all matters relating to librarianship. Last but not least, LMT2 focuses on the valuable pedagogical knowledge that helps all LMTs to uphold their roles efficiently and effectively in managing SRCs and teaching responsibilities.

In managing SRCs, there are a few challenges that LMTs face that is mostly linked to their heavy workload due to their participation in class teaching beyond the expected time (up to 25 hours from 12 hours), involvement in co-curricular activities and lack of supporting staff who are properly equipped with skills in school library work. Time is also connected with the heavy role of SRCs for class teachings, tutorials and seminars conducted by teachers during school hours due to class relief and the additional classes held after official school/working time such as, at night and on weekends. LMT3, LMT4 and LMT5 highlighted these issues and believe that the school administration does not give adequate attention to the roles and functions of an $\mathrm{SRC}$ as it is treated as a place for teaching and learning activities between teachers and students, which is examination-driven. As such, the LMTs have to compete with other programs and are left with minimum time to perform their responsibilities accordingly especially in organizing promotions for information literacy education and reading. LMT3 and LMT4 shared the same concern over the financial budget allocated to SRCs. This has affected them in their ability to acquire and purchase library materials and equipment within a restricted budget. Lastly, LMT5 shared that as a whole, students who turn up to the SRC are limited to those who are required to attend and participate in the programs and classes set by teachers and school administration. This indicates that students' daily routines are packed with their studies in preparation for examinations and thus, they do not have adequate time to fully utilize library services, which at some point leads to LMTs not being able to play and perform their roles and functions effectively. 


\section{Discussions and Conclusion}

An enormous challenge to SRCs is to reinforce their roles particularly to help the nation address the 21 st century skills needed by the young generation as outlined in the 2013-2025 Malaysia Education Blueprint. The findings have revealed essential information in respect with the roles, functions and competencies of LMTs. Among the roles and functions of LMTs are library administration and operations, management of library and learning resources/materials, provision of information literacy education and reading programs, communication and cooperation with school administration, teachers and parents and, of course involvement in class teachings and co-curricular activities. As for the competencies needed by LMTs, it is found that the participating LMTs are parallel and complementary to their roles and functions (refer to figure 1 below). The highlighted competencies are library science and information management, information literacy skills, ICT skills, library promotion, human communication skills, pedagogical knowledge, space management and decoration design. Also, some challenges have been expressed by the LMTs in this study, which can disrupt the provision and delivery of SRC's services, facilities and programs towards supporting the goals of 21 st teaching and learning at schools.

All LMTs consistently agree that one of their primary roles and functions is to provide information literacy education and promotion of reading habits for both students and teachers. This falls in line with the 21 st century role of SRC set by MOE that SRCs should function to prepare Malaysians who are inculcated with a reading culture and well-equipped with information skills (ETD, 2016). However, as they are heavily burdened with other responsibilities such as class teaching tasks and involvement in co-curricular activities, in reality it seems that they can only organize and conduct such information literacy classes and reading programs on an occasional basis rather than having them regularly and on a continued basis. In fact, the issue of a heavy workload has been emphasized several times before in literature, for example by Aisah et. al (2018) and Kamal and Normah (2012). Significantly, another issue highlighted is with the lack of attention given by the school administration towards the roles and functions of SRCs as well as LMTs. This can be seen by the fact that space for SRCs are mainly used by teachers for classes that concentrate on student's examination preparations, leaving little time for implementation of SRCs' programs and activities.

Human communication skills and LMTs' role relating to communication and cooperation with school administration, teachers and parents complementing each other. It is important to create and maintain a good rapport with the entire school community especially in ensuring the SRCs will always be able to align with the mission and goals of their parent schools. An LMT has deliberately articulated the specific personal traits required by LMTs such as being passionate, creative, innovative, and also making their presence relevant to others and always becoming a resource person in all matters relating to the field of librarianship. In this regard, Haycock (2007) highlights that the visionary leadership of teacher librarians is said to be helpful in increasing the school principals' roles. Several traits are emphasized to be translated into actions such as initiative, confidence, risk-taking, communication and leadership skills. 


\section{Macrothink}

In order to attract more users to visit and use SRCs, the LMTs ascertain the need for competency in space management and decoration. This is to create a more welcoming and attractive library atmosphere, which should adapt to the liking and interest of the younger generation. IFLA School Library Guidelines (2015) urges school libraries to establish a social space open for cultural, professional, and educational events and even consider providing "makerspaces" for students. Makerspaces is a platform an SRC can use to provide computers and production equipment that enables students to participate in practical learning experiences, including the creation of information products. This can also be done by making full use of the digital resources, internet and social media to encourage a culture of participation among library users which thus, leads to a change in their role from information users to information creators.

One of the LMTs mentioned pedagogy as an important competency needed by an LMT in managing and supporting SRCs. Simultaneously, a heutagogy learning approach should also be adopted, whereby students should become self-determined learners and study at their own pace. According to Calvani et al. (2010), there has been a consensus today on the need for digital competence to pay attention to a more complex and conceptual aspect than to purely focus on the technical dimension of technology. In this context, as 21st century learners are heutagogic learners who are high-skilled learners (Blaschke \& Hase, 2015), they need to be flexible and responsive to new ideas and situations (Halsall et al., 2016). This should include the ability to comprehend the fundamental nature of technological phenomena, and also to know the implications of the utilization of web technologies, ethically and socially.

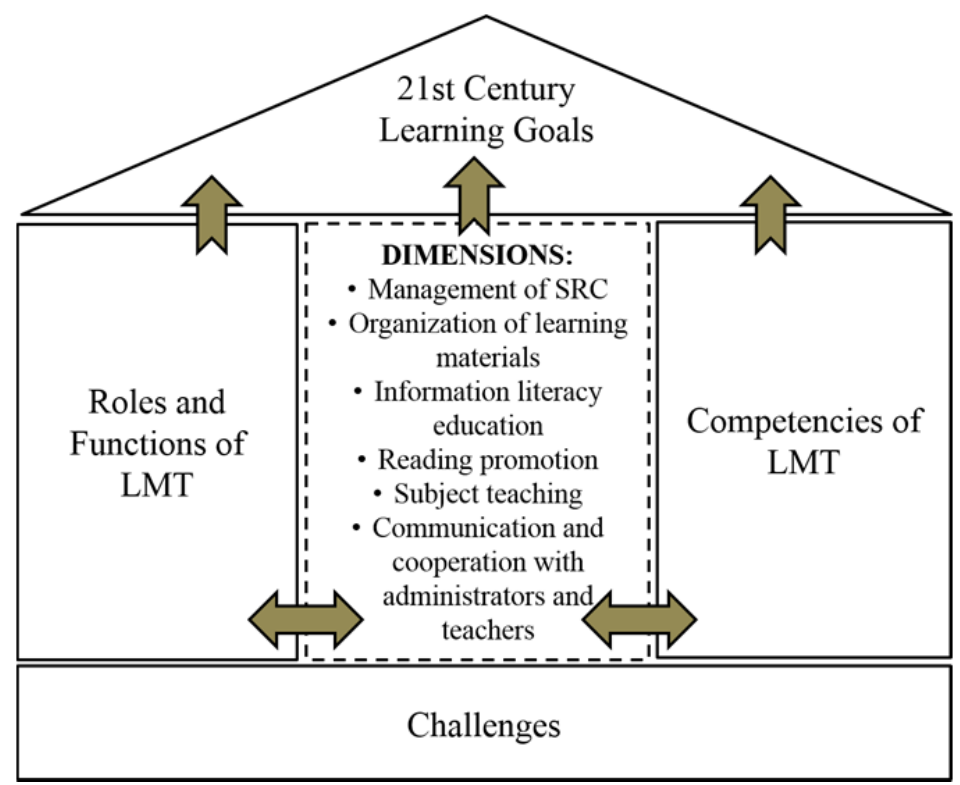

Figure 1. The Dimensions of Roles and Functions and, Competencies of LMT in Parallel, in Supporting 21st Century Goals. 


\section{Macrothink}

Figure 1 exhibits a general overview of the roles and functions of LMTs which should be parallel with the competencies needed by them as highlighted in 'Dimensions': management of $S R C$, organization of library/learning materials, information literacy education, reading promotion, subject teaching and, communication with school administrators and teachers. The dimensions are obtained based on the answers provided by the participating LMTs in the semi-structured interviews held, which are aligned with expectations as outlined by MOE. However, several challenges and obstacles faced by the SRCs and LMTs have disrupted the successful implementation of their roles and functions, especially in having heavy workloads with class teachings and participation in extra-curricular activities. This requires the attention of respective parties including the MOE, ETD, and school administrations to enforce and reinforce a culture that enables the LMTs to uphold their roles in preparing students who are inculcated with a reading culture, well-equipped with information skills and become lifelong learners as underlined in the 21 st century teaching and learning goals.

\section{Acknowledgement}

This paper was supported by Universiti Teknologi MARA, Malaysia (UiTM). 600-IRMI/Dana KCM 5/3/LESTARI (137/2017).

\section{References}

Aisah, M., Abrizah, A., Yanti Idaya Aspura, M., \& Wan Abd. Kadir, W. D. (2018). Development of an information literate school community: perceived roles and practices of teacher librarians. Malaysian Journal of Library and Information Science, 23(2), 63-75. https://doi.org/10.22452/mjlis.vol23no2.4

American Association of School Librarians (2010), 'ALA/AASL Standards for Initial Preparation of School Librarians,' American Association of School Librarians. Retrieved from http://www.ala.org/aasl/sites/ala.org.aasl/files/content/aasleducation/ schoollibrary/ (April 21, 2019).

Bahagian Teknologi Pendidikan. (2007). Program NILAM: konsep dan panduan pelaksanaan di sekolah (2nd ed.). Kuala Lumpur: Bahagian Teknologi Pendidikan, Kementerian Pelajaran Malaysia.

Blaschke, L. M., \& Hase, S. (2015). Heutagogy: a holistic framework for creating twenty-first-century self-determined learners. In The Future of Ubiquitous Learning (pp. 25-40). Springer Berlin Heidelberg.

Boyatzis, R. E. (1998). Transforming qualitative information: thematic analysis and code development. Thousand Oaks, California: Sage.

Calvani, A., Fini, A. \& Ranieri, M. (2010). Digital competence in K-12. Theoretical models, assessment tools and empirical research. Analisi, 40, 157-171. Retrieved from https://ddd.uab.cat/pub/analisi/02112175n40/02112175n40p157.pdf (November 10, 2019).

Cheng, P. Y. S. (2012). Perceiving usefulness: the perception of users on school libraries and librarians in Hong Kong. (Unpublished doctoral dissertation). Charles Sturt University, 
Wagga.

Creswell, J. W. (1998). Qualitative inquiry and research design: choosing among five traditions. Thousand Oaks, CA: Sage Publications.

Dike, V. W., Osadebe, N. E. and Babarinde, E. T. (2015). Competencies Required by Teacher Librarians for Stronger Primary School Libraries in Enugu State of Nigeria. IFLA WLIC 2015 in Session S02 - Satellite Meeting: Continuing Professional Development and Workplace Learning Section. In Taking Charge of your LIS Career: Personal Strategies, Institutional Programs, Strong Libraries, 12-14 August 2015, City of Cape Town, South Africa.

Fadzliaton Zainudin and Kamarulzaman Ismail (2010). Measuring Malaysia school resource centers'standards through iQ-PSS: an online management information system. In Diversity Challenge Resilience: School Libraries in Action, Proceedings of the 12th Biennial School Library Association of Queensland, the 39th International Association of School Librarianship Annual Conference incorporating the 14th International Forum on Research in School Librarianship, Brisbane QLD Australia, 27 September - 1 October 2010.

Halsall, J., Powell, J. L., Snowden, M. and Serpa, S. (2016). Determined learning approach: implications of heutagogy society based learning. Cogent Social Sciences, 2(1). https://doi.org/10.1080/23311886.2016.1223904

Hase, S., \& Kenyon, C. (2013). Self-determined learning: heutagogy in action. London, UK: Bloomsbury Academic.

Haycock, Ken. Collaboration: Critical success factors for student learning. School Libraries Worldwide, 13(1) (2007), 23-35.

International Federation of Library Associations (2015). IFLA School Library Guidelines (2nd Rev. ed.). Retrieved November 11, 2019, from http://www.ifla.org/files/assets/school-libraries-resource-centers/publications/ifla-school-libra ry-guidelines.pdf

Kamal M. A., \& Normah, O. (2012). The role of library and media teachers in Malaysian school resource center. Journal of Education and Practice, 3(15), 120-126.

Kementerian Pendidikan Malaysia (2016). Buku panduan pengurusan pusat sumber sekolah untuk guru perpustakaan dan media. Bahagian Teknologi Pendidikan, Kementerian Pendidikan Malaysia, Kuala Lumpur.

Kimmel, S. C., Dickinson, G. K., \& Doll, C. A. (2012). Dispositions in the twenty-first century school library profession. School Libraries Worldwide, 18(2), 106-120.

Kuhlthau, C. C. (2010). Guided inquiry: school libraries in the 21st century. School Libraries World Wide, 16(1), 17-28.

Lawrence, S. et al. (2001). Persistence of web references in scientific research. Computer, 34, 26-31. http://dx.doi.org/10.1109/2.901164 
Mohammad Jafre Abidin Zainol, Majid Pourmohammadi, Varasingam, Nalini and Ooi, C. L., (2014). The online reading habits of Malaysian students. Reading Matrix: An International Online Journal, 14(2), 164-172. Retrieved December 1, 2019, from http://www.readingmatrix.com/files/11-t91466a8.pdf

Ministry of Education of Malaysia. (2013). Malaysia Education Blueprint 2013-2025 (Preschool to Post-Secondary Education). Retrieved December 1, 2019, from https://www.moe.gov.my/ dasar/1207-malaysia-education- blueprint-2013-2025/file

Neuman, W. L. (2014). Social research methods: qualitative and quantitative approaches (7th ed.). Essex: Pearson.

Shuhidan, Shamila Mohamed. (2013). Information seeking processes among primary school children in Australia and Malaysia. (Unpublished doctoral thesis), RMIT University, Australia.

Shuhidan, Shamila Mohamed, Macauley, Peter and Reynolds, Sue (2011). Internet seeking by Australian school children: teachers' perspectives. Refereed paper presented to IADIS International Conference on Internet Technologies \& Society 2011, Shanghai, China, 8-10 December 2011.

Shuhidan, Shamila Mohamed, Macauley, Peter and Reynolds, Sue (2010). Using the internet for academic purposes: challenges for primary school children in Malaysia. Refereed paper presented to the IADIS Multi Conference on Computer Science and Information Systems 2010 Freiburg, Germany, 26 - 31 July 2010.

Soeters, K. E., \& Schaik, K. V. (2006). Children's experiences on the internet. New Library World, 107(1220/1221), 31-36. https://doi.org/10.1108/03074800610639012

Suhaini, Nurul Amanina (2016, April 4). 100 sekolah di Selangor perintis program NILAM. Berita Harian. Retrieved from https://www.bharian.com.my/node/140410 (December 1, 2019).

Tan, SM, Kaur, Kiran, K., \& Singh, D. (2015). Examining school librarians' readiness for information literacy education implementation. Malaysian Journal of Library and Information Science, 20(1), 79-97.

Yu, H. (2014). Conception, integration, and experiences of information literacy through project-based learning (Unpublished doctoral thesis). University Malaya, Kuala Lumpur.

Yushiana, M., \& Norhiyah, M. N. (2011). Use of the school resource centre among Malaysian high school teachers. Library Philosophy and Practice, 588. Retrieved December 1, 2019, from https://digitalcommons.unl.edu/libphilprac/588/ 


\section{Macrothink}

\section{Glossary}

AASL: American Association of School Librarians.

ALA: American Library Association.

ETD: Educational Technology Center.

ILSC: Information Literate School Community.

LMT: Library and Media Teacher.

MOE: Ministry of Education.

NILAM: an extensive reading program for school students in Malaysia.

SRC: School Resource Center.

\section{Copyright Disclaimer}

Copyright for this article is retained by the author(s), with first publication rights granted to the journal.

This is an open-access article distributed under the terms and conditions of the Creative Commons Attribution license (http://creativecommons.org/licenses/by/4.0/). 